IRSH 52 (2007), pp. 59-75 DOI: I0.10I7/S0020859007003 I 24

(C) 2007 Internationaal Instituut voor Sociale Geschiedenis

\title{
Revolution in a Comic Strip: Gasparazzo and the Identity of Southern Migrants in Turin, 1969-1975
}

\author{
Nicola Pizzolato
}

Summary: Between 1969 and I975, in Turin, a social movement with migrants from southern Italy as its protagonists addressed the issues of working conditions in the automobile plants, and housing and living standards in the city's overcrowded working-class neighbourhoods. Southern migrants, from different regions and speaking sometimes mutually incomprehensible dialects, forged a collective identity as Meridionali - "southerners" - and claimed recognition as fully fledged citizens of Turin's industrial society. This identity-building was captured in the making through the satirical cartoons featuring Gasparazzo, the character of a southern worker at FIAT who struggled daily with the alienation of work, the arrogance of supervisors, the repression enforced by the police, and, back in the south, the backwardness of the social system. Although the publication of Gasparazzo ended abruptly in 1972 the qualities of the cartoon character continued to resonate in succeeding years. As militancy waned and the social movement started to crumble, Gasparazzo came to symbolize the nostalgic model of a working-class hero rather than any actual southerner in the plant.

\section{"SE CHI LAVORA MANGIASSE, COSA MANGEREBBE CHI NON LAVORA?" I}

Between I 969 and I975, the automobile plants of Turin became the arena for a momentous social movement comprising the ranks of southern migrants from the Mezzogiorno. In I969 the Meridionali, as they were called, initiated a wave of spontaneous strikes centred on FIAT's factories, the Autunno Caldo, or "Hot Autumn", the period of the greatest mobilization of workers in Italian history, which opened the way to structural reforms of society. Meridionale - and its pejoratives like terrone - was a term with no particular meaning for the southern migrants, whose

I. "If those who work could eat, what would those who didn't work eat?", from Roberto Zamarin, I pensieri di Gasparazzo (Turin, I975), p. I. I would like to thank Rick Halpern, Axel Körner, and Chris Gordon for reading and commenting on an early draft of this article, and Simone Arcagni for his help with the iconography. 
identity was rooted in their villages or region (Sicily, Calabria, and so on). They lacked a communal notion of being part of a Meridione until they encountered northerners who were unacquainted with the differences throughout the south. The habits and dialects of the Meridionali varied, and southern Italy has a very diverse history so that, for example, Sicilians and Apulians could not understand each other's dialect. Only the shared experience of migration made communication with each other easier than with the Turinese.

Southerners transformed the workplace by resisting the adoption of the Fordist production process, or by embracing it but interpreting it with reference to their own cultural parameters. They affected union politics by bringing their own agenda to labour relations and by demanding inclusion in the system of industrial relations. In some cases, migrants espoused radical tactics and ideologies to advance their demands. The generation of protesters who struggled both inside and outside the factories of Turin in the late i960s and early i970s was bolder than the model of leftist militancy proposed by the communist union, the CGIL. Migrants vented their anger with loud performances, such as the rhythmic beating of machinery during processions, or by using aggressive slogans on their placards and uncompromising language in their publications.

This social movement was captured as it developed day by day through cartoons featuring Gasparazzo, a southern worker at FIAT who struggled with the alienation of work, the arrogance of supervisors, repression by the police, and the backwardness of the social system back home in the south. Gasparazzo appeared in the early i970s in the paper and leaflets of Lotta Continua, the New Left group that had the largest following in the automobile plants. Its author was Roberto Zamarin, a graphic designer from Veneto who gave up his professional career to work as cartoonist on Lotta Continua's newsletter, and his comic strip was the most frequently read part of that widely circulated publication; in fact its popularity required it to be edited into a book. ${ }^{2}$ Gasparazzo was popular not just because it encapsulated the main motives of the struggle, but also because its repertoire of jokes and wit were born of shared experience. In the years following the struggle, during a period of lay-offs and capital restructuring, Gasparazzo remained, in the memory of the disillusioned workers, an icon of the "typical" southern militant worker.

My aim here is to investigate the political significance of the Gasparazzo comic strip and to interpret it in the social context that produced it. I suggest that, years after publication ceased, the character of Gasparazzo remains a cultural reference to interpret the meaning of a profound transformation of industrial relations and of Turin's urban space. My sources are interviews with former Turinese and southern FIAT workers 
(some conducted by me, others found in the oral history collection of the FIAT archive), as well as leaflets, pamphlets, essays, and newsletters published by New Left groups from I969 to 1975. And of course there are the comic strips themselves.

\section{SOUTHERN MIGRATION IN TURIN}

Stalled in a rural economy for a century after Italian unification, the Italian south had traditionally been a pool of migrants. At the turn of the twentieth century Meridionali migrated to the Americas, while at the end of World War II their destination was northern Europe and, increasingly, as the country underwent an economic "miracle", Italy's own northwest. The industrial north offered them economic opportunities, for wages in manufacturing were more than three times those in agriculture. Young southerners were attracted by the lure of city life too, which contrasted markedly with the oppressive social order and the dull life of rural villages and provincial southern cities. ${ }^{3}$

Postwar Turin saw several waves of migration, mainly connected to the cycles of expansion in the automobile industry. In 1948 immigration started with Venetians and peasants from rural Piedmont, following the reconstruction of a city destroyed by war, and continued with Meridionali, peaking in the early I960s when Turin became the third "southern" city in Italy, after Naples and Palermo, in terms of the number of southern inhabitants. ${ }^{4}$ During the temporary recession of $1964-1966$, immigration slowed down considerably but another wave of Meridionali arrived between 1967 and 1969 as the automobile industry expanded again. Immigration from the south continued during the I970s although at a slowly decreasing rate, until it stopped in the I980s. ${ }^{5}$

In the I950s and early I960s, FIAT, under the leadership of its authoritarian manager Vittorio Valletta, had a policy of employing migrants only after they had acquired substantial experience in smaller industrial workshops and had assimilated the working habits of the Piedmontese. ${ }^{6}$ Furthermore, Valletta encouraged the recruitment of

3. Emilio Reyneri, La catena migratoria (Bologna, 1979); Guido Crainz, Storia del miracolo economico: culture, identità, trasformazioni fra anni cinquanta e sessanta (Rome, I996), pp. 83$\mathrm{I} 42$.

4. Italo Vignoli, “Torino: La città FIAT", in Roberto Mainardi and Carlo Tombola (eds), Grandi città e aree metropolitane, I: Città e spazi regionali d'Italia (Milan, I982), p. I43.

5. See Goffredo Fofi, L'immigrazione meridionale a Torino (Milan, 1962); Ugo Ascoli, Movimenti migratori in Italia (Bologna, 1979); Massimo Paci, Mercato del lavoro e classi sociali in Italia (Bologna, I973); Anna Anfossi, "Differenze socio-culturali tra gruppi piemontesi e meridionali a Torino", in idem (ed.), Immigrazione e Industria (Milan, I962); and Francesco Barbano and Francesco Garelli, "Struttura e cultura nell'immigrazione. Il caso di Torino", in Strutture della trasformazione. Torino 1945-1975 (Turin, 1980).

6. Piero Bairati, Valletta (Turin, I983), p. 203. 
friends and relatives of existing workers - the closer the relationship, the greater the chance of being taken on - a policy giving southerners only slim chances of finding work, despite the fact that the influx of migrants to the city during that period had been extraordinary. All that changed during the course of the I960s when the number of migrants who had experience of industrial work increased steadily, and so did the need for labour in the rapidly expanding FIAT works. ${ }^{7}$

In I967, FIAT opened a new plant at Rivalta, on the outskirts of Turin. At the time a small municipality of 5,000 people, Rivalta suddenly found itself with I I,6I 3 new workers, mainly migrants, many of whom brought along their families. Rents in Rivalta increased dramatically because of a complete lack of accommodation near the factory, and overcrowding led to a collapse of public and welfare services. At the same time, FIAT enlarged the existing Turinese plants, most notably its flagship Mirafiori, which then employed nearly 50,000 workers. ${ }^{8}$ As a result, within two years 60,000 more migrants moved into the metropolitan area of Turin.

FIAT managers were unmoved by requests from the city administration and the state to spread operations along the peninsula. They had pledged themselves to a production model demanding the maximum concentration of activities into a single metropolitan area. Until the Autunno Caldo, that is until urban problems risked jeopardizing its planned production output, FIAT refused to take any responsibility for the congestion of the city. Executive Giorgio Garino's assertion that "we make cars, let the GESCAL [Council House Agency] make houses" was typical of this attitude. ${ }^{9}$

\section{SOUTHERN MIGRANTS IN THE METROPOLIS}

The following strip from 1970 describes many of the issues that migrants confronted on arrival in Turin: high rents in the boarding houses, crowded hostels, and profiteers; the lack of options for accommodation, and the paradoxical "luck" of working all day to rest at night on a bunk bed in a dormitory. With a few strokes of his pen, Zamarin put in a nutshell the shared experience of the severe housing shortage in Turin which was a main cause of tension and an obvious sign of the impact of immigration.

7. Stefano Musso, "Gli operai di Mirafiori”, in Carlo Olmo (ed.), Mirafiori. 1936-1962 (Turin, 1997). Detailed statistics can be found in Archivio Storico FIAT, fondo Sepin; see also Giuseppe Berta, "Mobilitazione operaia e politiche manageriali alla FIAT, 1969-1979", in Stefano Musso (ed.), Tra Fabbrica e Società (Milan, 1999), p. 657.

8. Giuseppe Berta, Mirafiori (Bologna, I998), pp. 63-79; Stefano Musso, "Il lungo miracolo economico. Industria, economia e società (1950-1970)", in Nicola Tranfaglia (ed.), Storia di Torino, IX: Gli anni della repubblica (Turin, I999).

9. Valerio Castronovo, Torino (Bari, I985), pp. 423, 389; Fofi, L'immigrazione meridionale a Torino, p. 306; Giuseppe Berta, Conflitto industriale e strutture d'impresa alla FIAT, 1919-1979 (Bologna, I998), pp. I5I-I 52. 

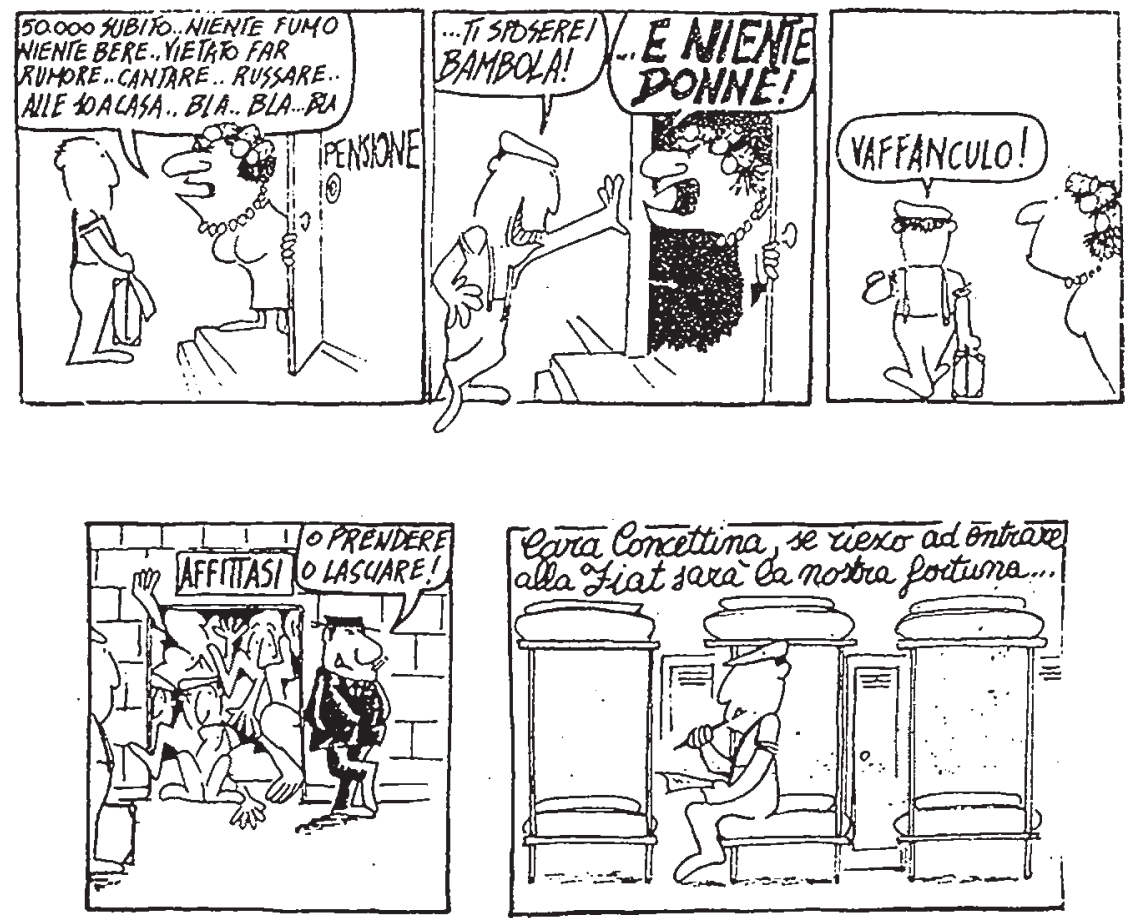

Figure I. 50,000 lire on the spot, no smoking, no drinking, no noise, singing, snoring, curfew at Io pm, blah ... blah ...; I would marry you, baby! ... And no women!; Fuck you!; "For rent”, take it or leave it!; Dear Concettina, if I managed to be hired at FIAT it would be our luck. Roberto Zamarin, Gasparazzo (Turin, I977)

Almost a decade earlier, in a study of migrants' integration into the urban scene, sociologist Magda Talamo, who methodically enquired into the housing conditions of the Meridionali, described the search for accommodation as "the most tormenting and immediate problem the migrant has to face on arrival". ${ }^{\text {10 }}$

In postwar Turin the apportionment of urban space indicated the ethnic and class divisions of its population. The Piedmontese regarded southerners as distinctly backward; uncouth, unclean, male chauvinist, and prone to violence. Meridionali were usually denied decent housing by the ubiquitous sign "We don't rent to southerners", and were instead forced into the attics and cellars of the city's old tenements, often managed by opportunists who, as in the strip above, took advantage of the lack of alternatives available to migrants. Southerners settled in the growing 
suburbs as well as in dilapidated inner-city buildings, but these suburbs were not an Italian version of the American "crabgrass frontier", enclaves of single-family houses with their own lawns. They were instead impoverished areas with crowded public housing or hastily built housing projects. An example was Vallette, a huge housing project built in 1958 at the far periphery of the city. Vallette housed 20,000 tenants, but the area was poorly connected to the city, which created de facto a segregation of its immigrant residents. The same applied to other peripheral areas, such as Nichelino and Falchera, small villages at the edge of the city which suddenly became home to thousands of migrants and came to media attention for their decay and lack of municipal services. ${ }^{\text {I }}$

For most of the Meridionali, coming on the night train from the south, Turin's Porta Nuova railway station provided the first impression of life in the north. Migrants received an immediate grasp of the geographical and social remoteness of their own origins. "I arrived at Porta Nuova one morning in November 196I", tells a Sicilian migrant straight from Messina with two suitcases and no address, "[w]hen I stepped outside I couldn't see anything, only a grey and humid wall; I could hear the city and imagine it, but I couldn't see it. At home, I didn't even know what fog looked like." ${ }^{2}$ Meridionali arrived at Porta Nuova with the "sunshine train", as it was called, a railway line that started from both Palermo and Syracuse, in Sicily, to join at the southern end of the Boot and then run up through many of the poor regions of the Mezzogiorno. Some arrived from Sardinia on a boat to Genoa followed by a two-hour train journey to Turin. Others arrived by train from the north of Europe - Belgium, Germany, and France - where they had worked as miners, construction workers, and carpenters. As interviews conducted at the time show, many migrants travelled back and forth between their southern villages and northern European destinations, finally stopping halfway in Turin. Still an alien environment for many, it was a place where "at least they talk Italian". ${ }^{13}$

Porta Nuova was also a temporary shelter for those who did not have contacts in the city. Often, "temporary arrangements" would last for weeks, accommodation was so scarce. Another arrangement was "bed-

I I. IRES, Rapporto preliminare nell'area ecologica di Torino (Turin, I97I); Castronovo, Torino, p. 389; Giuseppe Dematteis, "Torino dai borghi alla cintura”, in Roberto Mainardi (ed.), Le grandi Città Italiane (Milan, 1982); Città di Torino - Assessorato all'urbanistica, Torino e $i$ comuni della prima e seconda cintura. Analisi della situazione dei servizi pubblici (Turin, 1974). For a general discussion see Massimo Paci, "L'integrazione dei meridionali nelle grandi città del Nord", Quaderni di Sociologia, 3 (1964), pp. 22-38, and Stefano Musso, "Lo sviluppo e le sue immagini. Un'analisi quantitativa. Torino 1945-1970", in Fabio Levi and Bruno Maida (eds), La Città e lo sviluppo. Crescita e disordine a Torino 1945-1970 (Milan, 2002), pp. 39-59.

I 2. Interview with Pino B. in Marco Revelli, Lavorare in Fiat (Milan, I989), p. 28.

I3. Fofi, L' immigrazione meridionale a Torino, pp. 98, 9 I. 
sharing": two or three Meridionali working on different shifts would share the same bed in a rented room. If single, migrants often lived in boarding houses, where they would sleep "in bunches, one above the other in bunk beds [...] with seven lavatories for a hundred and twenty persons" and where the food was poor. ${ }^{\mathrm{I}}{ }^{4}$ When a television crew went to visit one of the slums, they interviewed southern tenants who, in badly spoken Italian, complained that "only animals could live here". is

\section{SOUTHERNERS BECOME INDUSTRIAL WORKERS}

In the workplace, as in the neighbourhoods, the Piedmontese welcomed migrants with circumspection. For Turinese FIAT worker Pietro Borretto, "many Meridionali had pretensions of several kinds. Some of them asserted they had come, as a matter of fact, to change FIAT. We replied that FIAT had been built, just as it was, by our ancestors." ${ }^{16}$ For another fellow worker, "When Meridionali come here they expect to change everything, even the weather." ${ }^{17}$ An early theme in the accounts of encounters between north and south is the allegation that Meridionali wanted rights but no obligations. Meridionali were not accustomed to the pace of the job in the Fordist factory, and they rejected the organization of the work more vehemently than their Piedmontese workmates. Meridionali also lacked a sense of belonging. For the natives, FIAT was inextricably linked to their forefathers as generation after generation in the same family toiled in the automobile plants. Natives were aware that the city's entire economy had developed around the car manufacturer. For the southerner, it merely symbolized his condition as a migrant and reminded him how far he had travelled from his roots.

Another recurrent theme running through the interviews with Piedmontese workers is the migrant's "laziness", or lack of work ethic. Some Meridionali "were always busy doing nothing". ${ }^{8}$ This was more than a simple stereotype as it reflected a true cultural distance between the two groups, a gap that widened with the last wave of Meridionali, those hired in I 969 directly from the south. For the generation of Piedmontese workers whose experience at FIAT pre-dated Valletta's reorganization of production in the I950s, or for those who had absorbed the Piedmontese work ethic through family or community, there still existed the myth of the

I4. Lotta Continua leaflet, I 2 May i970, Centro Piero Gobetti, Fondo Marcello Vitale, Carte Bobbio, box E2, folder VI.

I 5. Documentary Sapere: pregindizio, dir. Giuseppe Ferrara (RAI teche, I970).

I6. Archivio Storico FIAT, interview with Pietro Borretto, n. 2-04.

17. Archivio Storico FIAT, interview with Domenico Del Pero, n. I-i 5.

I8. Archivio Storico FIAT, interview with Pietro Borretto, n. 2-04. 
worker who shaped the elements of nature and created a product with his own hands and skill.

Among the native population, that myth served as a touchstone, and it was even stronger among the left-wing union militants, though it was also present in the Catholic tradition. ${ }^{19}$ Indeed, for historians Luisa Passerini and Marcella Filippa, "precisely for those who defined themselves as militants, skills and work ethic were the conditio sine qua non to be in action, to establish relations of trust with other workers, to be able to negotiate at the various levels of the hierarchy". ${ }^{20}$ The substance of this ethic consisted in seeing work as duty, a necessary burden that moulded workers' personal identities, and eventually led to self-esteem and selfrealization. FIAT fostered and valorized this illusion through outmoded practices such as the accomplishment of a so-called "masterpiece" - the manual completion of a part of the car, necessary to the worker for promotion to a higher category - clearly an obsolete and useless exercise in an era of standardized components.

In all his work Zamarin builds on the strength of migrants' vision of industrial work. Gasparazzo gave legitimacy to their different perception of factory work. Southerners confronted the mass-production process without any cultural reference to a mythical past of workers' control. Coming from an agrarian background, they considered work as fatica toil, physical effort - without an uplifting content. ${ }^{2 I}$ The strip below depicts Gasparazzo lifting a car body on his back. He is under the watchful eye of the same doctor who has monitored his progresses in one of the many sporting contests that the dopolavoro FIAT, the leisure department, organized for employees in a paternalistic attempt to channel workers' spare time within the activities of the firm. In an ironic twist to de Coubertin's creed, the background banner says: “The important thing is not to take part, but to produce". By portraying Gasparazzo as performing the same job as a packhorse, the strip conveyed the idea that southern migrants escaped the illusion of the "value" of work and its accompanying rhetorical and ideological baggage. The strip also ridicules FIAT's paternalistic policy of organizing workers' spare time after having sapped their physical strength during working hours: as Gasparazzo manages to lift the heavy weights the doctor remarks, "A great future awaits you!"

Before the Autunno Caldo, leftist sociologists such as Adalberto Minucci, Saverio Vertone, and Giuseppe Bonazzi argued that migrants' lack of an "industrial culture" was what caused their alienation from class

19. For analogies between communist and Catholic workers see Liliana Lanzardo Personalità' operaia e coscienza di classe. Comunisti e cattolici nelle fabbriche torinesi del dopoguerra (Milan, I987).

20. Luisa Passerini and Marcella Filippa, "Memorie di Mirafiori", in Olmo, Mirafiori, p. 34I.

21. Giuliana Saladino, Terra di Rapina (Turin, I977), touches upon this subject. 

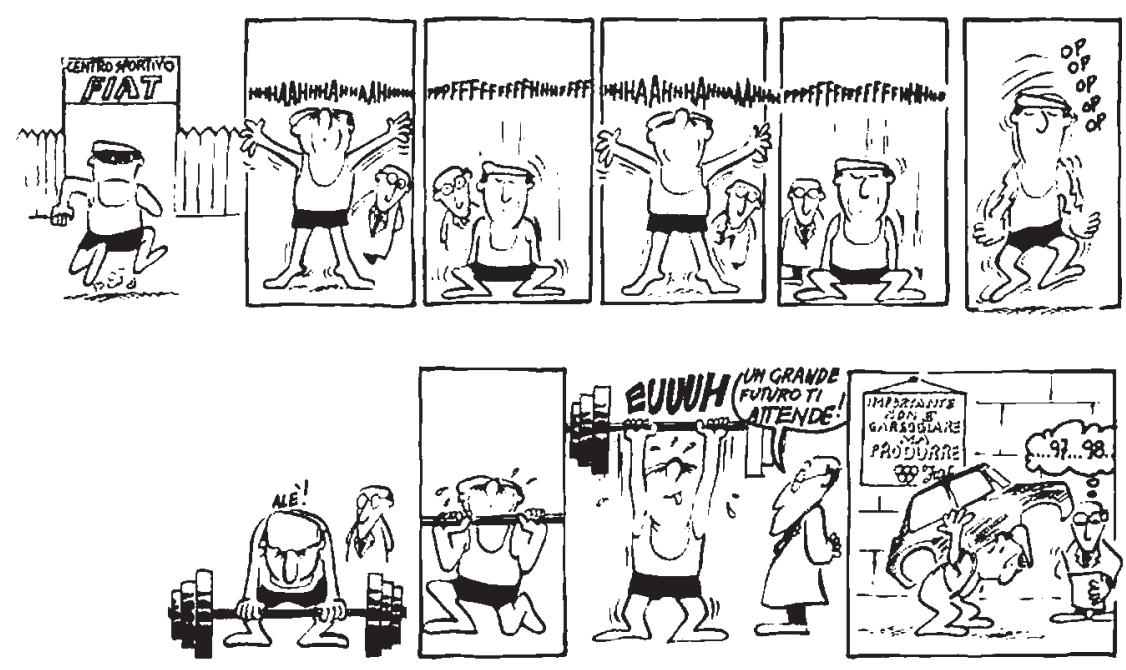

Figure 2. Gasparazzo and sport.

Zamarin, Gasparazzo.

politics, ${ }^{22}$ a view also espoused by the leaders of FIOM (Federazione Impiegati Operai Metallurgici, the Italian Metalworking Federation). They considered a work ethic to be a precondition for the achievement of class-consciousness, and therefore a necessary and desirable weapon in the battle against capital. Without such an ethic, they argued, workers would become "integrated" into a capitalist system that could guarantee high levels of consumption for better-paid workers such as the automobile workers. The debate inside the Italian Communist Party (PCI) about the incorporation of migrants into the working class and into the PCI reflected this standpoint. Communists posited a model of "class integration" which would "situate migrant workers, shoulder to shoulder, with the advanced political vanguard of the native working class, in the context of international proletarianism". ${ }^{23}$

Through this kind of approach, the Old Left distanced themselves from

22. Giuseppe Bonazzi, Alienazione e anomia nella grande industria. Una ricerca sui lavoratori dell'automobile (Milan, I 964); Adalberto Minucci and Saverio Vertone, Il Grattacielo nel deserto (Rome, 1960); Sergio Garavini and Emilio Pugno, Gli anni duri alla FIAT (Turin, 1974); Renzo Gianotti, Gli operai della Fiat hanno cento anni (Rome, I999).

23. According to a foundational document that illustrated PCI policy towards southerners, as quoted in Paola Cinanni, Emigrazione e unità operaia (Milan, I974), p. I65. On communists and migrants in Turin in the I950s and I960s see Fiammetta Balestracci, "Immigrati e PCI a Torino 1950-1970", in Levi and Maida, La Città e lo sviluppo, pp. I20-184, where she argues that the PCI's policy towards Meridionali failed because the party's vision was limited to considering them instrumental to electoral politics. 
the newcomers and, sceptical of their militancy, assumed that the skilled and "conscious" workers should take the lead in a possible resurgence of conflict at FIAT. Indeed there existed a basic contradiction between the unions' policy of "liberation through work" as opposed to the migrants' aim of "liberation from work", a contradiction that exploded dramatically in the autumn of $1969 .{ }^{24}$ Responding to working conditions inside the plant and to living conditions in the neighbourhoods, these migrants were more likely to transform their identity, not through training as industrial workers nor as members of "thrifty" northern society, but in the course of their struggle and through contact with the tiny radical Marxist groups that canvassed workers outside the factory. ${ }^{25}$

\section{SOUTHERNERS DURING THE AUTUNNO CALDO}

In 1969, industrial conflict at FIAT took on a chaotic dimension. Meridionali put egalitarian demands at the top of their agenda, which drastically diverged from the culture of the organization of the Old Left, such as the PCI and the CGIL, which had traditionally represented metalworkers. As we have seen, these groups regarded workers' skills as the cornerstone of the bargaining process, a standpoint that could not mobilize unskilled southerners, most of whom came from a rural background. Instead, the insurgent southern rank and file was in the process of forging an explosive alliance with the revolutionary student movement that swept the universities of Turin and all Italy in 1968.

At the end of virtually every shift, students and workers gathered in informal meetings to discuss what action was to be taken and to produce leaflets for distribution at the gates the following day. These groups sparked off a bold critique of the established unions, accusing them in particular of reluctance to champion a protracted struggle for an acrossthe-board wage increase. ${ }^{26}$ In June 1969 they started using the name La Lotta Continua [“The Struggle Goes On”]. Andrea Papaleo, a southerner taken on at Mirafiori in I969, told an interviewer:

So far, I've never had a chance to listen to them [the radicals of Lotta Continua] in person. I agreed with their aims and I liked their language. It was simple, direct, not like that of the unions, which seldom distributed leaflets and the few

24. I have borrowed these terms from Claus Offe, Disorganized Capitalism (Cambridge, 1985 ), p. 156.

25. "FIAT is our university" reads one of migrants' placards in a picket line. Quoted in Diego Giachetti (ed.), Oltre il Sessantotto: prima, durante e dopo il movimento (Pisa, 1998), p. 46.

26. For a survey of these events see Robert Lumley, States of Emergency: Cultures of Revolt in Italy from 1968 to 1978 (London, I990); Marco Revelli, "Movimenti Sociali e Spazio Politico", in Storia dell'Italia Repubblicana - La trasformazione dell'Italia: sviluppo e squilibri, vol. II (Turin, I995); Giachetti, Oltre il Sessantotto. 
times they did they were incomprehensible anyway. My encounter with politics began in this way. I started to attend meetings regularly with other workers. I attended gladly because I could always learn something new and free of charge! ${ }^{27}$

In their meetings with fellow migrant workers and northern students, southerners like Papaleo became familiar with the revolutionary ideology that inspired the militant organizations, groups that specifically rejected the parliamentary road to power and, with different emphases, advocated the empowerment of workers through direct action. L'Unità, the official newspaper of the PCI, accused them of "dividing the workers to the advantage of the master - FIAT" ${ }^{28}$ The "small groups" were in reality a mass of workers, and allegations like that indicated the legitimate fear within already weakened trade unions that they would lose their grip on the rising labour movement.

In Italy the two groups with the greatest following were Lotta Continua and Potere Operaio ["Workers' Power"]. They repudiated some key tenets of the labour movement, including discipline at work, the desirability of skills, and the usefulness of delegation. They scorned prolonged negotiations and regarded contracts only as bases for new demands. From operaismo [workerism] these radical groups learned to pay attention to the "mass worker" and to the factory as the vehicle and locus of a revolutionary change to society. ${ }^{29}$ Consequently, they adopted the direct language and slogan of the young migrant workers: "vogliamo tutto e subito" - "we want everything and we want it now". For a FIAT worker "workers started using the students as their writers. They came out of the factory and said: 'Today this and that happened, write it all up'." $3 \circ$

Students and workers built a loose organizational structure too, which they called the Student-Worker Assembly. At its opening meeting, a worker from the Mirafiori body shop declared:

Today we can make it with our own means. We don't need any union representation anymore, or nobody else's. This means that we now decide not only the form of the struggle, but also its goals, the style of its leadership, the way of organizing it and spreading it. This is what the manufacturers and union bureaucrats alike are more afraid of. ${ }^{3 \mathrm{I}}$

On the eve of the Autunno Caldo, the period of the most intense labour

27. Interview with Andrea Papaleo, in Gabriele Polo, I Tamburi di Mirafiori. Testimonianze operaie attorno all'autunno caldo alla Fiat (Turin, 1989), p. 2 I 2.

28. "La Fiat ricatta minacciando sospensioni”, L'Unità, 2 June 1969.

29. For references to operaismo see Renato Panzieri, Spontaneità e Organizzazione. Gli anni dei Quaderni Rossi (Pisa, 1994).

30. Cited in Guido Borio, Francesca Pozzi, and Gigi Roggero, Futuro Anteriore. Dai "Quaderni rossi" ai movimenti globali: ricchezze e limiti dell'operaismo italiano (Rome, 2002), p. I07.

31. Quoted in Diego Giachetti and Marco Scavino, La Fiat in mano agli operai (Pisa, 1999), p. 38 . 
unrest in Italian history, these words articulated a state of disaffection unprecedented at FIAT. They also testify to the ultimate failure of the plans of the company's leaders to defuse the class struggle within its plants. It was, in fact, the assurance that left-wing militancy had been subdued which led FIAT managers, under the leadership of Giovanni Agnelli after Valletta's death, to abandon their traditional policy of carefully screening job applicants at a time when consumer demand for automobiles was experiencing a rapid increase. For Turinese automobile worker, Vincenzo Damiano, "when FIAT needed to, it made no distinctions. The company hired a whole crowd of ruffians without any previous information. When I was taken on they asked everywhere about who I was."

In the course of 1969 FIAT hired no fewer that I 5,000 migrants directly from the south, most of them without any previous industrial experience. These workers augmented the thousands of Meridionali already employed during the I950s and I960s, but in contrast to their forerunners the new men could not make a favourable comparison between the steady employment conditions at FIAT and the unstable situation in the "secondary sector" of small workshops, many of them subcontractors for FIAT. They were therefore primed and ready to respond to the inhumane pace of the assembly line and problematic safety conditions they encountered on the shop floor. It was this group of marginalized workers who fuelled the new type of protest in $1969 .{ }^{32}$

One worker, Armando Bianchi, recalls that "these people were quite upset [...] some used to sleep at the railway station [...] they came to work, but they could not integrate into society". ${ }^{33}$ However, migrants rebelled against not only their precarious housing situation, but the plant's hierarchy too and the condition of exploitation at work. The situation on the shopfloor was analogous to their experience as hired farmhands in that bosses had the same arbitrary powers of discipline. Traditions of southern resistance, such as instances of "standing up to the big man", were imported into the new setting. ${ }^{34}$ Under the astounded gaze of their Piedmontese fellow workers, young Meridionali adopted a confrontational stance to foremen: "Listen, Mr Supervisor [...] I'm not afraid of you", threatened a migrant who had been reproached for working too

32. A point made by Giuseppe Berta, Conflitto Industriale e Struttura d'Impresa alla Fiat 19191979 (Bologna, I998), p. 87; Archivio Storico FIAT, interview with Vincenzo Damiano, n. 2-Io; Sergio Bruno, "The Industrial Reserve Army, Segmentation and the Italian Labour Market", Cambridge Journal of Economics, 3 (1979), pp. I3 I-I 5 I.

33. Archivio Storico FIAT, interview with Armando Bianchi, n. 2-o I.

34. For Alessandro Portelli, "narrators everywhere relish narratives of 'standing up to the big man', theatrical anecdotes of personal confrontation in which workers stand up to bosses (especially in stories of union negotiations), rank and file to leaders, students to teachers, soldiers to officers, in complex representations of personal courage, professional pride, or political resistance". See Alessandro Portelli, The Battle of Valle Giulia: Oral History and the Art of Dialogue (Madison, WI, 1997), p. 7. 

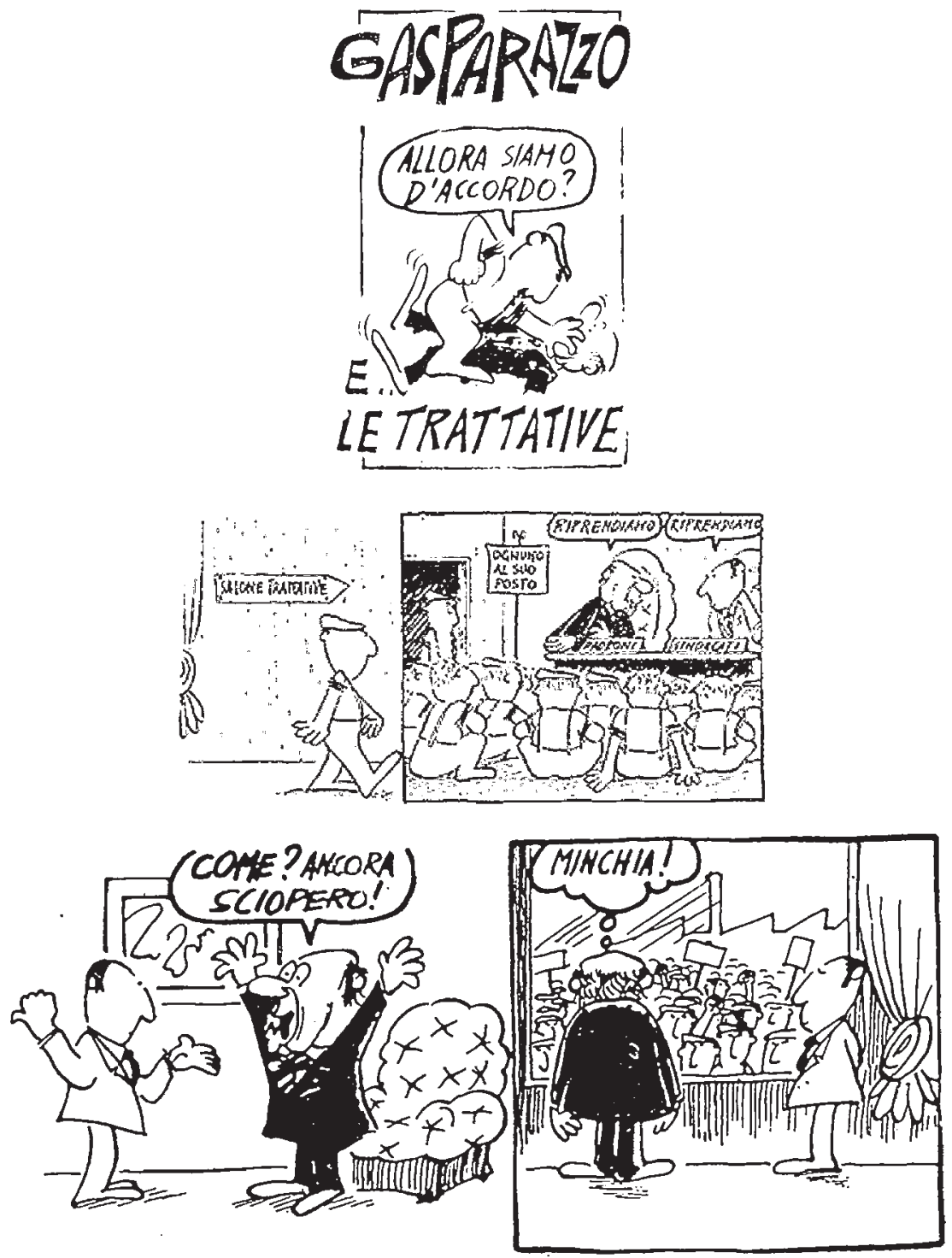

Figure 3. Gasparazzo and collective bargaining. "So, have we reached an agreement?" (Placard on the wall: "Everyone in his place"); Manager: "Please, you first"; Union leader: "No, please, you first"; (later): "Strike? Again?”; "Fuck it”.

Zamarin, Gasparazzo. 
slowly. "I'm twenty-three; even if I spend the next twenty years in jail, I will still be young when I'm released, but you won't be there when they let me out." 35 One worker remarked: "It was Meridionali with their rudeness (maleducazione) who started to break up the discipline." ${ }^{6} 6$

Disrespect, boldness, excessive virility, and proneness to violence were also the features of the Meridionale, Gasparazzo, in the comic strip of Zamarin, who was a northerner. That representation echoed some of the stereotyped traits northerners had used to describe Meridionali since the onset of immigration. ${ }^{37}$ In the strips of Zamarin though, these features are portrayed sympathetically as desirable characteristics of a Lotta Continua militant. In an ironic twist, what a few years before had been considered an obstacle to integration in the community was now represented as a model.

In the strip above, Gasparazzo is impatient with the negotiations between unions and bosses, which he sees as a reciprocal exchange of courtesies on the bargaining table, leaving the workers in the role of passive audience. A more effective way to carry out negotiations with the management is through the energetic persuasion of strikes, even without the approval of union leaders, who are portrayed as unable to control the workforce, distant from the daily experience of the shopfloor, and unenthusiastic about collective action. In another strip, union leaders and managers engage in a ping-pong match, which in Italian symbolizes the offloading of responsibilities on to each other to escape blame. The language of both leaders is verbose, full of technicalities, and incomprehensible, implying that industrial relations jargon couched a swindle at the expense of workers.

Rather than representing a realistic commentary on the political and social attitudes of Meridionali ("I was not the typical Gasparazzo", remarked a southern militant of the Autunno Caldo ${ }^{3}$ ), the comic strip proposed, ironically and with self-confidence, a stereotyped ideal of the southern activist member of one of the "extra-parliamentary" groups such as Lotta Continua. In fact, the point of view of Gasparazzo on unions, negotiations, collective contracts, and labour law coincided with that of the militants and leaders of Lotta Continua, although Gasparazzo displayed sarcastic detachment towards politics as a whole, even those of Lotta Continua. In that sense, the strip had an educational role towards its readers. For Lotta Continua leader Luigi Bobbio, Gasparazzo was a character "who in the struggle fulfils himself and his human nature", and whose interest in the working class goes beyond the factory and the

35. Archivio Storico FIAT, interview with Pietro Borretto, n. $2-04$.

36. Interview with Luciano Parlanti in Polo, I Tamburi di Mirafiori, p. 53.

37. Nicola Pizzolato, "Una situazione sado-masochistica ad incastro. Il dibattito scientifico sull'immigrazione meridionale (1950-1970)", Quaderni Storici, I 8 (2005), pp. 97-I 20.

38. Interview with Giuseppe Gambino, April 200I, in the possession of the author. 
industrial north to reach out to the social problems of all the masses, including unemployed southerners who had remained in the south. ${ }^{39}$ One of the strengths of Zamarin's fictional character was to impersonate the worker whom Lotta Continua hoped to mould.

On the other hand, Gasparazzo portrayed the southerner as a rebel with a cause, the real agent of social change, a representation that diverged from the idea of Meridionale as politically backward, obedient to religion and authority, passive or even reactionary, and an "unconscious" worker. Those were views that had been cultivated by both the Old Left and FIAT managers, and so Gasparazzo, although inherently a stereotypical figure, was for southern workers a better icon to identify with. Gasparazzo was a working-class anti-hero framed in the way that northerners saw southerners, but who bore the positive quality of fighting (and winning) against injustice both in the northern factory and back home in his southern village, where his fiancée Concettina perpetually awaited his return.

\section{THE MEMORY OF GASPARAZZO}

In Italy, the period from I970-I975 saw an expansion of workers' intervention in the organization of production and the fight against safety hazards, as well as increased participation in the policies of the unions. However, that was not the landscape that the New Left had envisaged for the years after the Autunno Caldo. Lotta Continua, for instance, predicted the growth of a revolutionary organization from the bottom up in absolute contrast to union organization. Adriano Sofri wrote in September I969: "We expect a widening gap between proletarian struggles and the political control of those struggles by the labour movement." ${ }^{\circ}$ It was a seriously short-sighted view and a political mistake, during the Autunno Caldo, for the radicals to take for granted the demise of unions. On the contrary, by slowly giving in to rank-and-file demands, unions had implemented a strategy to win back moderate workers, to "act militant", and to counteract the radicals, without appearing to threaten the social order.

In the early I970s, the unions showed an unexpected capacity to adapt to the needs of the Meridionale mass worker. It was the unions that managed the new balance of power emerging in the factories after the Autunno Caldo. Nationally too, unions launched a campaign for social reform. The Statuto dei Lavoratori (I97I), a comprehensive reform of labour law, incorporated many of the demands of the rank and file, although it substantially consolidated the position of the trade unions with regard both to the manufacturers and to the radical groups. The Statuto contained 
clauses to protect union rights in the workplace and several provisions extending the rights of workers and limiting employers' arbitrary power to remove or discipline workers. As the radical leftist groups soon recognized, the Statuto aimed to institutionalize the type of spontaneous militancy that the Autunno Caldo had generated, and to channel workers' militancy in the direction of reformism, for instance to the expansion of the Italian welfare state, rather than towards revolutionary goals. ${ }^{4 \mathrm{I}}$

In that period the radical Left proved itself still able to lead workers in episodic outbursts of anti-capitalist revolt, both on the shopfloor and in the community, but, on the whole, the New Left lacked a broader strategy that could offer the same real gains, in the factories and in the reform of the state, that the official union movement delivered. In the early i 970 s radical revolutionary propaganda appeared to have a certain appeal in relation to specific goals, but it did not provide a realistic political outlet for the working class.

Soon after Roberto Zamarin's accidental death in 1972, the kind of social movement comprising thousands of Meridionali which his comic strip depicted was on the wane. In the following years, large firms such as FIAT restructured by spreading their operations along the peninsula and abroad, and by relying more on minor firms to produce components. The "mass worker" in a huge plant like Mirafiori lost his paradigmatic power of representation of the whole working class, as the numbers of workers in small workshops increased. At the same time, the factory worker was more integrated into capitalistic labour relations due to the increased protection now offered by the state. A leftist commentator encapsulated these changes in the phrase "Gasparazzo is not eternal". ${ }^{42}$ If he existed at all, Gasparazzo was now working in the automated FIAT plant at Melfi, in the southern half of the Boot, rather than in Turin.

In I980, FIAT announced the lay-off of 23,000 workers, but with a cassa integrazione salary paid by the state for two years. It was, FIAT believed, a precondition for ensuring higher productivity and the launch of new competitive models. Such a drastic measure inevitably led to a collision with the unions, now one of the most important protagonists in the political arena. Between September and October i980 a thirty-five-day strike paralysed the Turinese plants, but it took place in the context of increased division among the several components of the workers' movement and dwindling public sympathy for the strikers. The episode resulted

4I. See Mario Abrate, Lavoro e Lavoratori nell' Italia Contemporanea (Milan, I977); Giovanni Contini, "Politics, Law, and Shop Floor Bargaining in Postwar Italy", in Steven Tolliday and Jonathan Zeitlin (eds), Shop Floor Bargaining and the State: Historical and Comparative Perspectives (Cambridge, 1985); Miriam Golden, Labor Divided: Austerity and Working-Class Politics in Contemporary Italy (Ithaca, NY, 1988).

42. Bruno Longo, "Meno salario, più reddito: la Cassa integrazione", Primo Maggio, 5 (1975), p. 30. 
in a defeat for the labour movement as resounding and symbolic as the success of the Hot Autumn had been. "What would Gasparazzo have done?", wondered a retired worker twenty years later, thinking of his best friend, who had been dismissed in I 980.43 The I 980 lay-offs had reversed the balance of power on the shopfloor and made Gasparazzo a nostalgic model of a working-class hero who had completely disappeared from industrial plants where, once again, managers had gained the upper hand in regulating industrial relations.

43. Interview with Pasquale De Stefani, April 2001, in the possession of the author. 